\title{
Response of a two-year sugar beet-sweet sorghum rotation to an agronomic management approach diversified by soil tillage and nitrogen fertilisation
}

\author{
A. Domenico Palumbo, ${ }^{1}$ A. Vittorio Vonella, ${ }^{1}$ Pasquale Garofalo, ${ }^{1}$ Laura D’Andrea, ${ }^{1}$ \\ Michele Rinaldi²
}

\author{
${ }^{1}$ Consiglio per la Ricerca e la Sperimentazione in Agricoltura - Unità di Ricerca per i Sistemi \\ Colturali degli Ambienti caldo-aridi (CRA-SCA), Bari; ${ }^{2}$ Consiglio per la Ricerca e la \\ Sperimentazione in Agricoltura - Centro di ricerca per la Cerealicoltura (CRA-CER), Foggia, Italy
}

\begin{abstract}
Conservative agriculture and nitrogen fertilisation have been evaluated for the purpose of assessing their impact on the sustainability of a cropping system based on a two-year rotation with two crops considered for the bio-ethanol supply chain: sugar beet (Beta vulgaris L. subsp. vulgaris) and sweet sorghum (Sorghum bicolor L. Moench). The experimental activity started in 2009 in Foggia (Apulia, southern Italy). We discuss the results obtained in the 2010-2011 period. Soil minimum tillage (MT) $v s$ no tillage (NT) combined with two doses of nitrogen fertilisation (75 and $150 \mathrm{~kg} \mathrm{ha}^{-1}$ of mineral nitrogen as ammonium nitrate) were compared. The experimental system, which is still operational (soil
\end{abstract}

Correspondence: A. Domenico Palumbo, Consiglio per la Ricerca e la Sperimentazione in Agricoltura - Unità di Ricerca per i Sistemi Colturali degli Ambienti caldo-aridi (CRA-SCA), via Celso Ulpiani 5, 70125 Bari, Italy. E-mail: domenico.palumbo@entecra.it

Key words: bio-ethanol chain, biomass crops, conservation tillage.

Conference presentation: SIA XLII Congress, Reggio Calabria, 2013.

Acknowledgements: this research was carried out within the framework of the National Research Project named Optimization of existing bioenergy chains for economic and environmental sustainability (Ottimizzazione delle filiere bio-energetiche esistenti per una sostenibilità economica e ambientale) (BIOSEA, D.M. 16916/7303/10, 23 July 2010).

Funding: Ministry of Agriculture, Food and Forestry Policies (MiPAAF), Italy. Coordinator: Prof. Gianpietro Venturi, Alma Mater Studiorum, Bologna University.

Received for publication: 4 December 2013.

Revision received: 7 April 2014.

Accepted for publication: 19 April 2014.

(C) Copyright A.D. Palumbo et al., 2014

Licensee PAGEPress, Italy

Italian Journal of Agronomy 2014; 9:568

doi:10.4081/ija.2014.568

This article is distributed under the terms of the Creative Commons Attribution Noncommercial License (by-nc 3.0) which permits any noncommercial use, distribution, and reproduction in any medium, provided the original author(s) and source are credited. tillage plus nitrogen fertilisation), was arranged with a split-plot design with three replicates. Treatments were applied on the same plots every year with both crops present at the same time. At the first harvest in 2010 , no difference was observed. As to the second year, the comparison between NT $v$ MT treatments showed that sugar beet had lower total yield ( $35 v s 42 \mathrm{t} \mathrm{ha}^{-1}$ ), dry biomass (10 vs $14 \mathrm{t} \mathrm{ha}^{-1}$ ), and sucrose yield (6.7 vs $8.2 \mathrm{t} \mathrm{ha}^{-1}$ ). Total soluble solids, on average $19 \%$, were not influenced by the experimental treatments. Nitrogen (N) control was less productive than the fertilised treatments (average between N75 and $\mathrm{N} 150$ ) in terms of total fresh root yield (32 vs $42 \mathrm{t} \mathrm{ha}^{-1}$ ), dry biomass (10 vs $14 \mathrm{t} \mathrm{ha}^{-1}$ ), and sucrose yield (6.0 vs $\left.8.1 \mathrm{t} \mathrm{ha}^{-1}\right)$. As with sugar beet, during the second year, also sweet sorghum sown in NT $v$ MT plots had a reduced yield, although the difference was more marked for fresh biomass $(-35 \%)$ than for dry biomass $(-20 \%)$. No interaction in terms of soil tillage nitrogen fertilisation occurred.

In summary, in the first two-year period (2010-2011) of the experimental trial, no tillage soil management showed decreased yields of both crops. Sugar beet displayed a higher sensitivity to the lack of nitrogen supply than sweet sorghum.

\section{Introduction}

Most areas of the Mediterranean basin are characterised by a negative water balance, a short and irregular rainy season, extreme temperatures in the summer, loss of organic matter, poor structuring of the soil, high salinity. These areas are often exposed to water and/or wind erosion, and desertification processes (Kassam et al., 2012).

Some agricultural practices, mainly soil tillage and crop residue management, can exacerbate these conditions, therefore agronomic research suggests adopting techniques like no tillage and/or minimum tillage, which do not disturb the soil and retain or improve its chemical and physical properties.

The adoption of conservation agricultural practices favours a balanced distribution of fertilisers, meets crop nutrient requirements, and offers an efficient management of irrigation water (Kassam et al., 2012; Scopel et al., 2013). Among the soil management systems, reduced soil tillage can contribute to the reduction of erosion, the maintenance and/or improvement of soil fertility as well as the increase of biodiversity. The minimum tillage and/or no tillage systems are well-proven for the production of cereals, however they can have a negative impact on weeded crops, like sugar beet, when shallow and non-inversion farming techniques are adopted (Koch et al., 2009). Other long-term benefits of conservative soil tillage consist in the 
improvement of the soil structure and the water infiltration, but also an increase in the cation exchange capacity, in comparison with conventionally tilled systems (Wight et al., 2012). In this study, two types of agronomic management techniques were compared in relation to soil tillage and mineral nitrogen fertilisation, in order to assess their impact on the sustainability of a cropping system based on a two-year rotation of two crops considered for the bio-ethanol supply chain: sugar beet (Beta vulgaris L. subsp. vulgaris) and sweet sorghum (Sorghum bicolor L. Moench).

Between 1975 and 2005, sugar beet was among the most interesting crops in the cropping systems of Southern Italy. It was considered as the classical weeded crop that opened the rotation with cereals (i.e. durum wheat) and vegetables (i.e. processing tomato). For a long time, this crop was successful as a result of the following factors: i) the autumn seeding which allowed to exploit the rain of the autumnwinter season; ii) the water deficit irrigation management during the following spring-summer season; iii) the availability of cultivated varieties suitable to specific soil and climate conditions, and resistant to bolting, also if sown in autumn; iv) the harvest in early or midsummer, which ensured the best management of soil tillage for the following crop in the crop sequence (Cavazza, 1983; Venturi, 1988; Rinaldi, 2012).

Once the crop disappeared from the cropping systems of Southern Italy, in particular in Apulia, as a consequence of the new European Community agricultural policy, the know-how associated with it remained in any case unchanged in local farms. This could be considered a pre-condition for the reintroduction of sugar beet as an energy crop in the rotated cropping systems either for multiple purposes or strictly for the bio-ethanol supply chain (Venturi and Venturi, 2003).

Sweet sorghum is the other crop considered in the two-year rotation under study, since it produces a highly appreciated raw material as an alternative source for ethanol production (Audilakshmi et al., 2010). Fast growth rate and early harvesting season, great adaptability to poor soils, high water and nutrient use efficiency are among its pluses that make this crop so suitable to several agricultural areas in the Mediterranean basin (Curt et al., 1995; Mastrorilli et al., 1995, 1999; Habyarimana et al., 2004; Barbanti et al., 2006; Garofalo et al., 2011).

This work aims to demonstrate how these crops, managed with low external inputs over a medium-term period, can both respond with an affordable yield and safeguard the agro-ecosystem, avoiding wastes of fertilisers, water, and energy.

\section{Materials and methods}

The experimental activity was performed from 2009 to 2011 in Foggia, Podere 124 farm, of the CRA-SCA (lat. $41^{\circ} 8^{\prime} \mathrm{N}$, long. $15^{\circ} 83^{\prime} \mathrm{E}$, alt. $90 \mathrm{~m}$ asl). The site was classified as a Typic Calcixeret (Soil Survey Staff, 2010). In the first 0.5 m-deep layer, mainly containing the roots of the considered crops, the soil is silty-clayey (sand $=13.0 \%$, silt $=43.6 \%$, clay $=43.4 \%$ ) and is characterised by: $\mathrm{pH}=8.3$, total organic carbon (C) $=35.7 \mathrm{~g} \mathrm{~kg}^{-1}$, total nitrogen $(\mathrm{N})=1.2 \mathrm{~g} \mathrm{~kg}^{-1}, \mathrm{C} / \mathrm{N}=10$. As to its hydrological characteristics, the field capacity water content and the permanent wilting point water content are $0.396 \mathrm{~m}^{3} \mathrm{~m}^{-3}$ and $0.195 \mathrm{~m}^{3}$ $\mathrm{m}^{-3}$, respectively. The readily available soil water content is $45 \%$ of the total soil water content. The climate is accentuated thermoMediterranean (UNESCO-FAO, 1963). Temperature can drop below $0^{\circ} \mathrm{C}$ in the winter and can exceed $40^{\circ} \mathrm{C}$ in the summer, while yearly longterm class A pan evaporation is $1604 \mathrm{~mm}$ (1033 mm during the sugar beet cycle, $657 \mathrm{~mm}$ for sorghum). Rain (yearly average $=549 \mathrm{~mm}$ in the 1952-2008 period) is unevenly distributed and mostly concentrated between October and January (on average, $233 \mathrm{~mm}$ ).
A two-year sugar beet-sweet sorghum rotation was considered. Two treatments, namely soil tillage and nitrogen fertilisation, were arranged in a factorial split-plot design with three replicates. The treatments were applied on the same plots, in such a way that both crops were present every year by rotating them. The main treatment was related to the type of soil tillage management, while the secondary treatment consisted in the fertilisation process with two doses of mineral nitrogen.

Minimum tillage (MT) was compared with no tillage (NT) combined with direct sowing. In particular, the MT treatment was performed by chopping the residues of the previous crop (durum wheat) in 2009, in mid-November. Residue chopping was followed by weed control (glyphosate, $5 \mathrm{~L} \mathrm{ha}^{-1}$ ), shallow ploughing $(20-25 \mathrm{~cm})$ with a five-furrow plow, phosphate fertilisation ( $100 \mathrm{~kg} \mathrm{ha}^{-1}$ of $\left.\mathrm{P}_{2} \mathrm{O}_{5}\right)$, and seed bed preparation. Ploughing and seed bed preparation were not foreseen in the NT treatment.

Mineral nitrogen fertilisation was applied with 75 (N75) and 150 (N150) $\mathrm{kg} \mathrm{ha}^{-1}$ of nitrogen in the form of ammonium nitrate (34\%) and was compared with an unfertilised area (N0).

In the MT treatment area, seeding was performed with a precision driller, whereas in the NT treatment area a Gaspardo No-Till 1040 driller was used to sow the seeds at a depth $<0.05 \mathrm{~m}$, after light and shallow tillage in the strip area affected by the furrowers.

The main plot (soil tillage) and sub-plots (nitrogen fertilisation) were $24 \times 74 \mathrm{~m}$ and $7 \times 12 \mathrm{~m}$, respectively.

The rotated crops were sugar beet (cv Autave) and sweet sorghum (cv Sucro 506) with field densities at harvesting of 10 and 20 plants $\mathrm{m}^{-2}$ respectively.

Irrigation of both crops was applied according to a deficit irrigation scheduling for sugar beet (50\% of irrigation requirement) and full irrigation for sorghum (100\%). The crop irrigation requirement was estimated using the soil water content measurements in the 0-80 cm depth (gravimetric method), then the amount of water to replace the soil field capacity for the same soil depth was calculated. In order to ensure uniform water distribution, a drip irrigation system was used with one line for each plant row and drippers with a $4 \mathrm{~L} \mathrm{~h}^{-1}$ flow.

Sugar beet was sown on $24^{\text {th }}$ November 2009 and $2^{\text {nd }}$ December 2010 respectively in the first and second year of the trial. Mineral $\mathrm{N}$ fertilisation was applied at the beginning and in the middle of May, respectively in 2010 and 2011. During the crop cycles, two and four irrigations were performed for total water volumes of 900 and $1100 \mathrm{~m}^{3} \mathrm{ha}^{-1}$ respectively in the first and the second year of the trial. Harvest was on $21^{\text {st }}$ July 2010 and $9^{\text {th }}$ August 2011.

Sweet sorghum was sown on May $7^{\text {th }}$ in both years of the trial. Nitrogen fertilisation was applied on $5^{\text {th }}$ July 2010 and $23^{\text {rd }}$ June 2011. During the crop cycles three and seven irrigations were applied, for total water volumes of 1230 and $2120 \mathrm{~m}^{3} \mathrm{ha}^{-1}$ respectively in the first and second year of the trial. Harvest took place at the heading stage on $12^{\text {th }}$ August 2010 and $5^{\text {th }}$ September 2011.

The following parameters were determined: i) for sugar beet, the weight of total fresh and dry biomass (roots and leaves); ii) for sweet sorghum, the weight of fresh and dry biomass (leaves, stems, and panicle). The harvest sampling areas were $36 \mathrm{~m}^{2}$ and $12 \mathrm{~m}^{2}$ respectively for sugar beet and sweet sorghum. The dry weight was obtained by drying the vegetable samples in a ventilated oven at $70^{\circ} \mathrm{C}$, until a constant weight was reached. For both crops total soluble solids (TSS) content in ${ }^{\circ}$ Brix was measured by PR model 32 ATAG0 Palette digital refractometer. For sugar beet, the theoretical sucrose yield $\left(\mathrm{t} \mathrm{ha}^{-1}\right)$ was calculated by multiplying fresh root yield and TSS. For sweet sorghum, total solids (TS, \%) were derived from the ratio between dry and fresh biomass weights.

The irrigation water use efficiency (IWUE, $\mathrm{kg} \mathrm{m}^{-3}$ ) and the nitrogen use efficiency (NUE, $\mathrm{kg} \mathrm{kg}^{-1}$ ) were calculated by using the ratio 
between the yield (fresh root biomass and sucrose yield for sugar beet; plant fresh and dry biomass yield for sorghum) and the irrigation water supplied (IWUE) and the nitrogen applied (NUE), respectively.

The data were analysed by using the statistical analysis software SAS/STAT ${ }^{\circledR}$ (SAS Institute Inc., Cary, NC, USA). The analysis of variance was performed taking into account the adopted experimental design separately for each year. Mean separation was made with the least significant difference test at a significance level of $\mathrm{P} \leq 0.05$.

\section{Sugar beet}

First year: 2009-2010 (Table 1). As was said before, no difference was reported between the experimental treatments in the first year. On average, fresh root yield was $41.2 \mathrm{t} \mathrm{ha}^{-1}$. However, roots at harvest were characterised by a high content of TSS, $19.4^{\circ}$ Brix on average, which gave a theoretical sucrose yield of $8 \mathrm{t} \mathrm{ha}^{-1}$ on average. This value is considered the cost-effectiveness threshold for sugar beet in Southern Italy.

No statistical differences were observed in terms of both soil

\section{Results}

\section{Climate}

In the two cropping seasons, from sugar beet sowing to sorghum harvesting, minimum temperature (Tmin), maximum temperature (Tmax), and monthly cumulative rainfall followed the climatic longterm trend of the experimental site (1952-2008) (Figure 1).

During the winter, the monthly Tmin fluctuated between $3-4^{\circ} \mathrm{C}$ (2010) and $2-4^{\circ} \mathrm{C}$ (2011), while, during the summer, in particular in the months of July and August, the monthly Tmax was around $34^{\circ} \mathrm{C}$. As to rainfalls, the cumulative value of the 2009-2010 cropping season was $+17 \%$ compared with the corresponding value for the long-term period (525 vs $450 \mathrm{~mm}$ ), while, in the 2010-2011 cropping season, it was closer to the value for the long term period ( $495 v s 496 \mathrm{~mm}$ ). In both cases, rainfalls were concentrated between 0ctober and April. Some exceptions need to be underlined for the purposes of this study. In the 20102011 growing season, Tmin was lower than $2.2^{\circ} \mathrm{C}$, and Tmax was higher than $2.4^{\circ} \mathrm{C} v s$ the corresponding values of the long-term period, respectively in December 2010 and August 2011. In May 2011, the rainfall value was $101 \mathrm{~mm}$ (39 mm in the long period). In 2010 and 2011, August was characterised by a complete absence of rainfall which, together with very high temperature peaks (the so-called heat waves), could have influenced the final stage of the crop cycles of both sugar beet and sweet sorghum.

\section{Crops}

The statistical analysis of crop production variables did not show any significant variation in the first year, neither in terms of main effects nor of interaction, except for NUE for both crops. In the second year, several production variables and resource efficiency indices showed significant variations in terms of main effects.

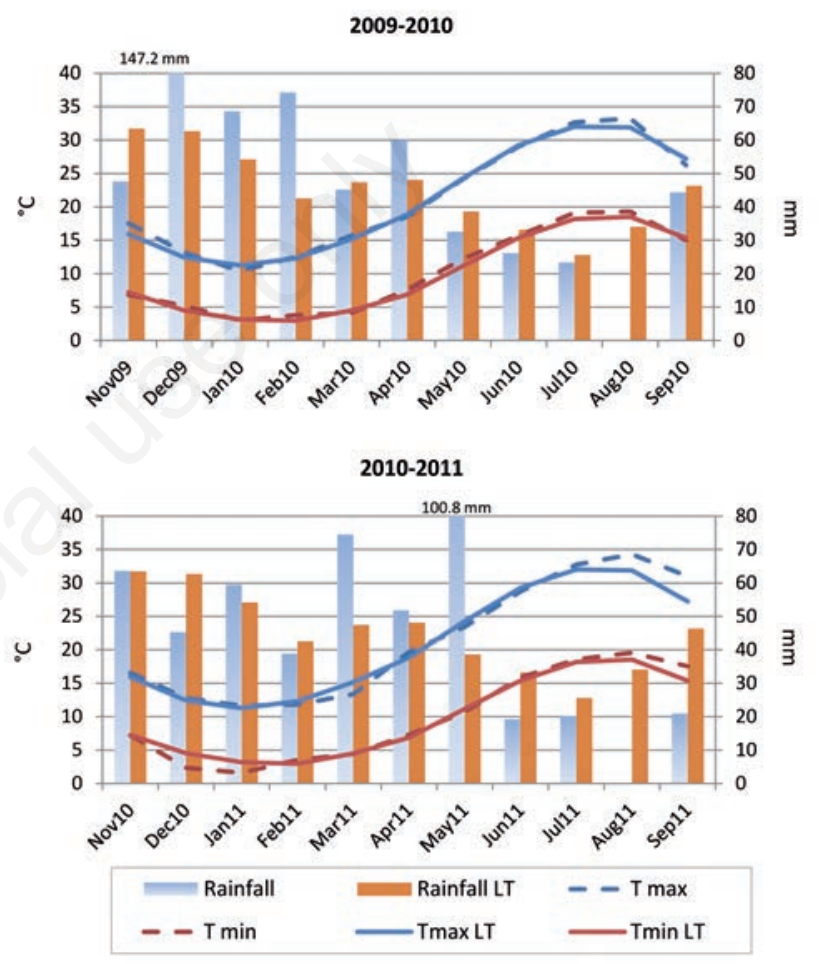

Figure 1. Climate description of the two cropping seasons (20092010 and 2010-2011) compared to long-term data (Foggia, 19522008).

Table 1. Yield response of sugar beet, total soluble solids, irrigation water use efficiency for fresh roots yield and sucrose yield, nitrogen use efficiency for fresh root yield and sucrose yield as influenced by soil tillage and fertilisation treatments in the first year of the trial, Foggia, 2009-2010.

\begin{tabular}{|c|c|c|c|c|c|c|c|c|}
\hline Treatment & $\begin{array}{l}\text { Roots yield } \\
\mathrm{t} \mathrm{ha}^{-1}\end{array}$ & $\begin{array}{c}\text { Dry biomass } \\
\mathrm{t} \mathrm{ha}^{-1}\end{array}$ & $\begin{array}{l}\text { TSS } \\
{ }^{\circ} \text { Brix } \\
\end{array}$ & $\begin{array}{c}\text { Sucrose } \\
\mathrm{t} \mathrm{ha}^{-1}\end{array}$ & $\begin{array}{l}\operatorname{IWUE}_{\mathrm{y}} \\
\mathrm{kg} \mathrm{m}^{-3}\end{array}$ & $\begin{array}{l}\text { IWUE }_{\text {suc }} \\
\mathrm{kg} \mathrm{m}^{-3}\end{array}$ & $\begin{array}{l}\mathrm{NUE}_{\mathrm{y}} \\
\mathrm{kg} \mathrm{kg}^{-1}\end{array}$ & $\begin{array}{l}\mathrm{NUE}_{\text {suc }} \\
\mathrm{kg} \mathrm{kg}\end{array}$ \\
\hline MT & 40.1 & 13.7 & 19.1 & 7.7 & 44.5 & 8.6 & 412.0 & 79.4 \\
\hline NT & 42.4 & 14.2 & 19.6 & 8.3 & 47.1 & 9.2 & 432.1 & 84.0 \\
\hline No & 38.9 & 12.7 & 19.4 & 7.6 & 43.2 & 8.4 & - & - \\
\hline N75 & 41.9 & 14.1 & 19.2 & 8.1 & 46.6 & 9.0 & $558.9^{\mathrm{a}}$ & $107.5^{\mathrm{a}}$ \\
\hline N150 & 42.8 & 15.1 & 19.6 & 8.4 & 47.5 & 9.3 & $285.2^{\mathrm{b}}$ & $55.8^{\mathrm{b}}$ \\
\hline 2009-2010 & 41.2 & 14.0 & 19.4 & 8.0 & 45.8 & 8.9 & 422.1 & 81.6 \\
\hline
\end{tabular}

TSS, total soluble solids; IWUE, irrigation water use efficiency for fresh roots yield; IWUE suc $_{\text {, }}$ irrigation water use efficiency for sucrose yield; NUE, nitrogen use efficiency for fresh root yield; NUE suc $_{\text {, nitrogen use }}$ efficiency for sucrose yield; MT, minimum tillage; NT, no tillage; N, nitrogen. a,bValues followed by different letters within columns are significantly different (Fisher's least significant difference test, P $\leq 0.05$ ). 
tillage management and fertilisation doses. No difference was seen in IWUE for fresh roots and sucrose between the different types of soil tillage management. They were 47.1 and $9.2 \mathrm{~kg} \mathrm{~m}^{-3}$, and 44.5 and 8.6 $\mathrm{kg} \mathrm{m}^{-3}$, for the NT and the MT treatments respectively. The rising doses of nitrogen slightly increased IWUE. By doubling doses of nitrogen, its use efficiency (NUE) halved. For each $\mathrm{kg}$ of applied N, 559 vs $285 \mathrm{~kg}$ of fresh roots and 108 vs $56 \mathrm{~kg}$ of sucrose were derived respectively for N75 and N150 treatments.

Second year: 2010-2011 (Table 2). MT confirmed the production levels which were achieved previously in terms of fresh roots, dry biomass, TSS and sucrose yield. In contrast, sugar beet grown on NT soil for the second consecutive year evidenced a significant decrease of fresh roots and dry biomass $(-18 \%$ and $-24 \%$, respectively), and sucrose yield $(-18 \%)$, whereas TSS valve was similar to the NT treatment. As to nitrogen fertilisation, the results obtained with N75 and N150 treatments were similar. The unfertilised test area was found to be less productive than in the previous year, thus highlighting the sensitivity of sugar beet to the depletion of nitrogen in the soil, if external inputs are inadequate. As to NT and N0, the yield response of the crop was very low ( $26 \mathrm{t} \mathrm{ha}^{-1}$ of fresh root yield and $5 \mathrm{t} \mathrm{ha}^{-1}$ of sucrose yield; data not show). Contrary to what was observed in the first year, the IWUE was higher in the MT treatment (38.4 and $7.4 \mathrm{~kg} \mathrm{~m}^{-3}$ respectively for the fresh roots and the sucrose yield) than in NT treatment (31.4 and $6.1 \mathrm{~kg} \mathrm{~m}^{-3}$ ).

The effect of nitrogen was similar in N75 and N150 treatments which, anyway, exceeded by more than $30 \%$ the unfertilised test area (N0). This highlights that there is close link between water and nitro- gen availability and therefore an effect on the photosynthetic response and the final productivity of sugar beet. The nitrogen use efficiency was higher in MT than NT (on average, $+15 \%$ ). Like in the previous year, NUE was halved both for fresh roots and sucrose yields, when the dose of mineral fertiliser was doubled.

No significant effect of the interaction of soil tillage $x$ nitrogen fertilisation emerged from the examined variables.

\section{Sweet sorghum}

First year: 2010 (Table 3). There were no significant differences between MT and NT treatments with regard to fresh and dry biomass and TSS. N150 treatment produced a very limited increase of dry biomass (about $+2 \%$ ) compared with $\mathrm{N} 0$ and $\mathrm{N} 75$ (on average, $26.2 \mathrm{t} \mathrm{ha}^{-1}$ ), while it increased TSS content by $8 \%$.

The IWUE for dry biomass was 21.3 and $19.6 \mathrm{~kg} \mathrm{~m}^{-3}$ respectively in MT and NT treatments. The application of $150 \mathrm{~kg} \mathrm{ha}^{-1}$ of nitrogen promoted a slight increase of IWUE with respect to dry biomass $(+8 \%)$ and TSS (+14\%).

As to the dry biomass and sucrose content, the NUE values decreased by $95 \%$ and $61 \%$, respectively, when the doses of mineral nitrogen fertiliser were doubled.

Second year: 2011 (Table 4). Though the differences between the first and the second year were evident for fresh biomass (average decrease by about $35 \%$ ), on the other end dry biomass was reduced by $20 \%$. In fact, the plants showed at harvest higher values of TSS and TS with positive consequences from a qualitative point of view. This could also be due to a severe water stress as a consequence of the dryness

Table 2. Yield responses of sugar beet, total soluble solids, irrigation water use efficiency for fresh roots yield and sucrose yield, nitrogen use efficiency for fresh root yield and sucrose yield as influenced by soil tillage and fertilisation treatments in the second year of the trial, Foggia, 2010-2011.

\begin{tabular}{|c|c|c|c|c|c|c|c|c|}
\hline Treatment & $\begin{array}{l}\text { Roots yield } \\
\qquad \mathrm{t} \mathrm{ha}^{-1}\end{array}$ & $\begin{array}{c}\text { Dry biomass } \\
\mathrm{t} \mathrm{ha}^{-1}\end{array}$ & $\begin{array}{l}\text { TSS } \\
{ }^{\circ} \text { Brix }\end{array}$ & $\begin{array}{l}\text { Sucrose } \\
\mathrm{t} \mathrm{ha}^{-1}\end{array}$ & $\begin{array}{l}\text { IWUE }_{\mathrm{y}} \\
\mathrm{kg} \mathrm{m}^{-3}\end{array}$ & $\begin{array}{l}\text { IWUE }_{\text {suc }} \\
\mathrm{kg} \mathrm{m}^{-3}\end{array}$ & $\begin{array}{c}\mathrm{NUE}_{\mathrm{y}} \\
\mathrm{kg} \mathrm{kg}^{-1}\end{array}$ & $\begin{array}{l}\mathrm{NUE}_{\text {suc }} \\
\mathrm{kg} \mathrm{kg}^{-1}\end{array}$ \\
\hline MT & $42.3^{\mathrm{a}}$ & $13.7^{\mathrm{a}}$ & 19.3 & $8.2^{\mathrm{a}}$ & $38.4^{\mathrm{a}}$ & $7.4^{\mathrm{a}}$ & $445.7^{\mathrm{a}}$ & $87.6^{\mathrm{a}}$ \\
\hline NT & $34.6^{\mathrm{b}}$ & $10.4^{\mathrm{b}}$ & 19.3 & $6.7^{\mathrm{b}}$ & $31.4^{\mathrm{b}}$ & $6.1^{\mathrm{b}}$ & $390.1^{\mathrm{b}}$ & $75.6^{\mathrm{b}}$ \\
\hline No & $31.6^{\mathrm{b}}$ & $9.6^{b}$ & 19.0 & $6.0^{\mathrm{b}}$ & $28.7^{\mathrm{b}}$ & $5.5^{b}$ & - & - \\
\hline N75 & $41.7^{\mathrm{a}}$ & $13.6^{\mathrm{ab}}$ & 19.7 & $8.2^{\mathrm{a}}$ & $37.9^{\mathrm{a}}$ & $7.5^{\mathrm{a}}$ & $555.6^{\mathrm{a}}$ & $109.7^{\mathrm{a}}$ \\
\hline N150 & $42.0^{\mathrm{a}}$ & $14.1^{\mathrm{a}}$ & 19.2 & $8.0^{\mathrm{a}}$ & $38.2^{\mathrm{a}}$ & $7.3^{\mathrm{a}}$ & $280.2^{\mathrm{b}}$ & $53.5^{\mathrm{b}}$ \\
\hline $2010-2011$ & 38.4 & 12.4 & 19.3 & 7.4 & 34.9 & 6.8 & 417.9 & 81.6 \\
\hline
\end{tabular}

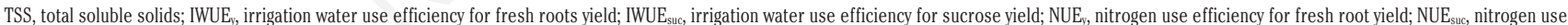
efficiency for sucrose yield; MT, minimum tillage; NT, no tillage; N, nitrogen. a,bValues followed by different letters within columns are significantly different (Fisher's least significant difference test, P $\leq 0.05$ ).

Table 3. Yield response of sweet sorghum, total soluble solids, total solids, irrigation water use efficiency for fresh biomass yield and dry biomass yield, nitrogen use efficiency for fresh biomass yield and dry biomass yield as influenced by soil tillage and fertilisation treatments in the first year of the trial, Foggia, 2010.

\begin{tabular}{|c|c|c|c|c|c|c|c|c|}
\hline Treatment & $\begin{array}{c}\text { Fresh biomass } \\
\mathrm{t} \mathrm{ha}^{-1}\end{array}$ & $\begin{array}{c}\text { Dry biomass } \\
\text { t ha }^{-1}\end{array}$ & $\begin{array}{l}\text { TSS } \\
\text { o }{ }^{\circ} \text { Brix }\end{array}$ & $\begin{array}{l}\text { TS } \\
\%\end{array}$ & $\begin{array}{l}\operatorname{IWUE}_{\mathrm{y}} \\
\mathrm{kg} \mathrm{m}^{-3}\end{array}$ & $\begin{array}{l}\text { IWUE }_{\mathrm{dm}} \\
\mathrm{kg} \mathrm{m}^{-3}\end{array}$ & $\begin{array}{c}\mathrm{NUE}_{\mathrm{y}} \\
\mathrm{kg} \mathrm{kg}^{-1}\end{array}$ & $\begin{array}{l}\mathrm{NUE}_{\mathrm{dm}} \\
\mathrm{kg} \mathrm{kg}^{-1}\end{array}$ \\
\hline $\begin{array}{l}\text { MT } \\
\text { NT }\end{array}$ & $\begin{array}{l}114.9 \\
110.3\end{array}$ & $\begin{array}{l}27.5 \\
25.3\end{array}$ & $\begin{array}{l}9.0 \\
8.5\end{array}$ & $\begin{array}{l}23.9 \\
23.0\end{array}$ & $\begin{array}{l}89.1 \\
85.5\end{array}$ & $\begin{array}{l}21.3 \\
19.6\end{array}$ & $\begin{array}{l}1532.0 \\
1470.7\end{array}$ & $\begin{array}{l}366.7 \\
337.3\end{array}$ \\
\hline $\begin{array}{l}\text { N0 } \\
\text { N75 } \\
\text { N150 }\end{array}$ & $\begin{array}{l}111.5 \\
109.4 \\
116.8\end{array}$ & $\begin{array}{l}26.3 \\
26.2 \\
26.7\end{array}$ & $\begin{array}{l}8.5 \\
8.4 \\
9.2\end{array}$ & $\begin{array}{l}23.6 \\
23.9 \\
22.9\end{array}$ & $\begin{array}{l}86.4 \\
84.8 \\
90.5\end{array}$ & $\begin{array}{l}20.4 \\
20.3 \\
20.7\end{array}$ & $\begin{array}{c}- \\
1458.7^{\mathrm{a}} \\
778.7^{\mathrm{b}}\end{array}$ & $\begin{array}{c}- \\
349.3^{\mathrm{a}} \\
178.0^{\mathrm{b}}\end{array}$ \\
\hline 2010 & 112.6 & 26.4 & 8.7 & 23.5 & 87.2 & 20.5 & 1123.7 & 263.6 \\
\hline
\end{tabular}

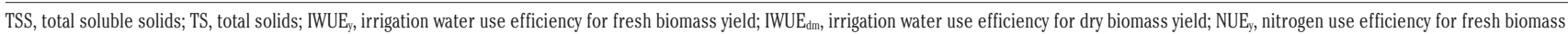
yield; NUE $\mathrm{dm}_{\mathrm{dm}}$, nitrogen use efficiency for dry biomass yield; MT, minimum tillage; NT, no tillage; N, nitrogen. a,bValues followed by different letters within columns are significantly different (Fisher's least significant difference test, $\mathrm{P} \leq 0.05)$. 
Table 4. Yield response of sweet sorghum, total soluble solids, total solids irrigation water use efficiency for fresh biomass yield and dry biomass yield, nitrogen use efficiency for fresh biomass yield and dry biomass yield as influenced by soil tillage and fertilisation treatments in the second year of the trial, Foggia, 2011.

\begin{tabular}{|c|c|c|c|c|c|c|c|c|}
\hline Treatment & $\begin{array}{l}\text { Fresh biomass } \\
\qquad \text { t ha }^{-1}\end{array}$ & $\begin{array}{c}\text { Dry biomass } \\
\mathrm{t} \mathrm{ha}^{-1}\end{array}$ & $\begin{array}{l}\text { TSS } \\
{ }^{\circ} \text { Brix }\end{array}$ & $\begin{array}{l}\text { TS } \\
\%\end{array}$ & $\begin{array}{l}\operatorname{IWUE}_{\mathrm{y}} \\
\mathrm{kg} \mathrm{m}^{-3}\end{array}$ & $\begin{array}{l}\text { IWUE }_{\mathrm{dm}} \\
\mathrm{kg} \mathrm{m}^{-3}\end{array}$ & $\begin{array}{c}\mathrm{NUE}_{\mathrm{y}} \\
\mathrm{kg} \mathrm{kg}^{-1}\end{array}$ & $\begin{array}{l}\mathrm{NUE}_{\mathrm{dm}} \\
\mathrm{kg} \mathrm{kg}^{-1}\end{array}$ \\
\hline MT & $78.1^{\mathrm{a}}$ & 22.1 & $13.1^{\mathrm{b}}$ & 28.4 & $69.7^{\mathrm{a}}$ & $19.7^{\mathrm{a}}$ & $1041.3^{\mathrm{a}}$ & $294.7^{\mathrm{a}}$ \\
\hline NT & $63.8^{\mathrm{b}}$ & 19.7 & $14.7^{\mathrm{a}}$ & 30.7 & $57.0^{\mathrm{b}}$ & $17.6^{\mathrm{b}}$ & $850.7^{b}$ & $262.7^{\mathrm{b}}$ \\
\hline N0 & 67.8 & 19.3 & 13.5 & 30.5 & 60.5 & 17.2 & - & - \\
\hline N75 & 69.0 & 20.9 & 14.3 & 28.2 & 61.6 & 18.7 & $920.0^{\mathrm{a}}$ & $278.7^{\mathrm{a}}$ \\
\hline N150 & 76.0 & 22.5 & 13.9 & 30.0 & 67.9 & 20.1 & $506.7^{\mathrm{b}}$ & $150.0^{\mathrm{b}}$ \\
\hline 2010-2011 & 70.9 & 20.9 & 13.9 & 29.6 & 63.3 & 18.7 & 713.3 & 218.8 \\
\hline
\end{tabular}

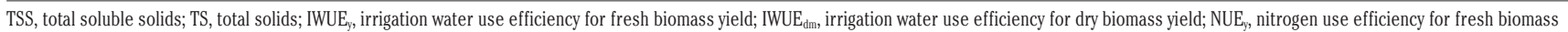
yield; $\mathrm{NUE}_{\mathrm{dm}}$, nitrogen use efficiency for dry biomass yield; MT, minimum tillage; NT, no tillage; N, nitrogen. a,bValues followed by different letters within columns are significantly different (Fisher's least significant difference test, $\mathrm{P} \leq 0.05)$.

occurred in August 2011, just partially offset by deficit irrigation.

As was observed for sugar beet, in this second year, a yield reduction was reported with NT vs MT (-18\%), although the difference was significant for fresh, but not for dry biomass yield. In contrast, NT was more efficient than MT in relation to TSS.

Between the two types of soil tillage management, soil water content did not differ consistently, either at the time of sowing and at harvest (data not shown). The yield response to applied nitrogen doses was not significantly different.

The calculated IWUE values of dry and fresh biomass yields were significantly higher with MT $\left(19.7 \mathrm{~kg} \mathrm{~m}^{-3}\right)$ compared with NT $\left(17.6 \mathrm{~kg} \mathrm{~m}^{-3}\right)$. The NUE doubled by halving the dose of nitrogen, thus confirming the results obtained in the first year. With regard to the interaction of soil tillage and nitrogen fertilisation, no significant difference emerged in the examined production parameters.

\section{Discussion}

Despite the short time of the experiment, some useful indications have emerged.

Sweet sorghum gave a high fresh and dry biomass yield in both years, also with a deficit irrigation scheduling. It also proved to have a great potential under the climatic and soil management conditions reported above. High dry biomass accumulation $\left(26 \mathrm{t} \mathrm{ha}^{-1}\right)$ with small amounts of water applied (114 mm) was also underlined by Curt et al. (1995) about sweet sorghum grown in Spain. These productivity levels are comparable with those of biomass sorghum (Habyarimana et al., 2004) with a dry biomass accumulation (from 20 to $29 \mathrm{t} \mathrm{ha}^{-1}$ ) close to our experimental values under similar environmental and rainfall conditions. However different results were reported by Berenguer et al. (2001) with water irrigation volumes similar to those of our experiment (on average $168 \mathrm{~mm}$ ). He observed a dry biomass accumulation equal to $11.5 \mathrm{t} \mathrm{ha}^{-1}$, which is almost half if compared with the sorghum biomass observed.

The sorghum IWUE $\mathrm{dm}_{\mathrm{dm}}$ was very high, if compared to the values reported in literature and mainly to the results from sugar beet in this experiment. As shown by the field results, the efficiency of sweet sorghum in converting water into biomass was very high also when small amounts of water were applied, even if in the literature there are reports (Farrè and Faci, 2006) with values of IWUE $_{\mathrm{dm}}$, between 2.89 and $3.75 \mathrm{~kg} \mathrm{ha}^{-1}$, when shifting from optimal to stressed water conditions. Also in biomass sorghum, IWUE $_{\mathrm{dm}}$ triplicated, when water applied was decreased (from 4.38 to $12.42 \mathrm{~kg} \mathrm{~m}^{-3}$; Garofalo and Rinaldi, 2013), but it was heavily affected by the soil water content at sowing. Field trials and data from the literature clearly show that IWUE $_{\mathrm{dm}}$ in sorghum grown in the Mediterranean area can vary remarkably from 5.84 to $22.81 \mathrm{~kg} \mathrm{~m}^{-3}$, even with similar amounts of irrigation water applied, especially in reduced water regimes. This can be mainly explained by the amount and distribution of rainfalls, but also by the soil moisture content at sowing (Garofalo and Rinaldi, 2013).

Sugar beet gave a worse response for most measured parameters compared with sorghum. Rinaldi and Vonella (2006) reported in the same Mediterranean environment and under the same deficit irrigation conditions (on average $249 \mathrm{~mm}$ of irrigation and $353 \mathrm{~mm}$ of rainfall) values for fresh root yield ranging between 38.2 and $60 \mathrm{t} \mathrm{ha}^{-1}$ in three experimental years, which are very close to the results of our experiment obtained with $100 \mathrm{~mm}$ of irrigation water and $442 \mathrm{~mm}$ of rainfall water (average of the two seasons). In the same research (Rinaldi et al., 2006) the IWUE doubled in the wettest year (24 vs $15 \mathrm{~kg}$ $\mathrm{m}^{-3}$ ) and the average IWUE $\mathrm{E}_{\text {suc }}$ was $3.72 \mathrm{~kg} \mathrm{~m}^{-3}$.

In this study, despite the irrigation volumes were lower (less than $150 \mathrm{~mm}$ ) than the ones reported by the same authors, IWUE $\mathrm{E}_{\mathrm{y}}$ was $75 \%$ greater, probably due to a better rainfall distribution during the two growing periods ( $473 \mathrm{~mm}$ in the first and $410 \mathrm{~mm}$ in the second one, during sugar beet crop cycle). High variability of $\operatorname{IWUE}_{\mathrm{y}}$ as a consequence of water irrigation is confirmed also by Sepaskhah and KamgarHaghighi (1997) with values ranging from 19.1 to $44.4 \mathrm{~kg} \mathrm{~m}^{-3}$ when shifting from 2248 to $675 \mathrm{~mm}$ of irrigation water in two experimental years with a different rainfall pattern and very low values for IWUE $\left(0.54 \mathrm{~kg} \mathrm{~m}^{-3}\right)$. These experimental findings highlight the importance of the initial soil water content for the final yield performance of the crop.

Sugar beet and sweet sorghum proved to have a great capacity for exploiting the water stored in the soil, thanks to their deep root systems (Vamerali et al., 2003; Himmelbauer et al., 2004). In the two experimental years, the water stored in the two months before sowing (on average $144 \mathrm{~mm}$ for sugar beet and $125 \mathrm{~mm}$ for sorghum), and during the growing cycles, allowed the crops not to suffer from water stress, in spite of (and thanks to) deficit irrigation. This could explain the high value of IWUE, which corresponds to high productivity with low amount of irrigation water.

Moreover, sorghum is a crop with good nitrogen use efficiency (Gardner et al., 1994). For the same reason, the lack of response to nitrogen application is a common phenomenon observed in this crop. Indeed, $\mathrm{N}$ application had no impact on sweet sorghum growth and yield partitioning among plants organs (Barbanti et al., 2006). In addition, sugar yield did not change with $\mathrm{N}$ application (Wortmann et al., 2010). This implies that sweet sorghum can be cultivated with little $\mathrm{N}$ application with no negative impact on sugar content yield. A different 
response was observed in the sugar beet, which has a well-known sensitivity to $\mathrm{N}$ deficiency, that causes delays in leaf growth and canopy closure, accelerates leaf senescence, and reduces capture of solar radiation (Mildford, 1985; Draycott and Christenson, 2003).

\section{Conclusions}

No difference was identified between the experimental treatments in the first year of the discussed experimental trial in terms of neither the type of soil tillage management (minimum vs no tillage) nor the mineral nitrogen fertilisation. As for the results of the second year, no tillage appeared to adversely affect the growth of both examined crops, resulting in a reduced yield. Only the dry biomass of sweet sorghum was not different between the two types of soil tillage that were compared.

Sweet sorghum proved capable of exploiting the soil water content and transforming irrigation water in a very efficient way with very high yields in terms of both fresh and dry biomass. With regard to the response to mineral nitrogen fertilisation, sugar beet showed a higher sensitivity to the deficiency of external inputs, if compared with the results of sweet sorghum.

A comparative analysis of the energy balance and $\mathrm{CO}_{2}$ air emission in the six combinations of soil tillage and nitrogen fertilisation will allow a more accurate assessment of these crop management options.

The continuation of the planned experimental trial might give more useful long-term information on the capability of sugar beet and sweet sorghum of maintaining crop yield levels under conditions of no tillage and different nitrogen supply management methods.

\section{References}

Audilakshmi S, Mall AK, Swarnalatha M, Seetharama N, 2010. Inheritance of sugar concentration in stalk (brix), sucrose content, stalk and juice yield in sorghum. Biomass Bioenergy. 34:813-20.

Barbanti L, Grandi S, Vecchi A, Venturi G, 2006. Sweet and fibre sorghum (Sorghum bicolor (L.) Moench), energy crops in the frame of environmental protection from excessive nitrogen loads. Eur. J. Agron. 25:30-9.

Berenguer MJ, Faci JM, 2001. Sorghum (Sorghum bicolor L. Moench) yield compensation processes under different plant densities and variable water supply. Eur. J. Agron. 15:43-55.

Cavazza L, 1983. Output and input analysis in energy balance of agriculture production. Riv. Agron. 17:202-11.

Curt MD, Fernandez J, Martinez M, 1995. Productivity and water use efficiency of sweet sorghum (Sorghum bicolor (L.) Moench cv «Keller») in relation to water regime. Biomass Bioenergy. 8:401-9.

Draycott AP, Christenson DR, 2003. Nutrients for sugar beet production: soil-plant relationships. CAB International, Wallingford.

Farrè I, Faci JM, 2006. Comparative response of maize (Zea mays L.) and sorghum (Sorghum bicolor L. Moench) to deficit irrigation in a Mediterranean environment. Agric. Water Manage. 83:135-43.

Gardner JC, Maranville JW, Paparozzi ET, 1994. Nitrogen use efficiency among diverse sorghum cultivars. Crop Sci. 34:728-33.

Garofalo P, Rinaldi M, 2013. Water-use efficiency of irrigated biomass sorghum in a Mediterranean environment. Spanish J. Agric. Res. 11:1153-69.

Garofalo P, Vonella AV, Ruggieri S, Rinaldi M, 2011. Water and radiation use efficiencies of irrigated biomass sorghum in a Mediterranean environment. Ital. J. Agron. 6:133-9.

Habyarimana E, Bonardi P, Laureti D, Di Bari V, Cosentino S, Lorenzoni C, 2004. Multilocational evaluation of biomass sorghum hybrids under two stand densities and variable water supply in Italy. Ind. Crop Prod. 20:3-9.

Himmelbauer ML, Loiskandl W, Kastanek F, 2004. Estimating length, average diameter, and surface area of roots using two different image analysis systems. Plant Soil. 260:111-20.

Kassam A, Friedrich T, Derpsch R, Lahmar R, Mrabet R, Basch G, GonzálezSánchez EJ, Serraj R, 2012. Conservation agriculture in the dry Mediterranean climate. Field Crops Res. 132:7-17.

Koch HJ, Dieckmann J, Buchse A, Marlander B, 2009. Yield decrease in sugar beet caused by reduced tillage and direct drilling. Eur. J. Agron. 30:101-9.

Mastrorilli M, Katerii N, Rana G, 1999. Productivity and water use efficiency of sweet sorghum as affected by soil water deficit occurring at different vegetative growth stages. Eur. J. Agron. 11:207-15.

Mastrorilli M, Katerji N, Rana G, Steduto P, 1995. Sweet sorghum in Mediterranean climate: radiation use and biomass water use efficiencies. Ind. Crop Prod. 3:253-60.

Milford GFJ, Pocock TO, Jaggard KW, Biscoe PV, Armstrong MJ, Last PJ, Goodman PJ, 1985. An analysis of leaf growth in sugar-beet. 4. The expansion of the leaf canopy in relation to temperature and nitrogen. Ann. Appl. Biol. 107:335-47.

Rinaldi M, 2012. Sugar beet. In: P. Steduto, T. C. Hsiao, E. Fereres, D. Raes (Eds.), Crop yield response to water. FAO Irrigation and Drainage Paper 66, Rome, pp 200-208.

Rinaldi M, Di Paolo E, Vonella AV, 2006. Efficiency of water use in sugar beet (Beta vulgaris L.) and processing tomato (Lycopersicon esculentum Mill.) cropped in Southern Italy. Ital. J. Agron. 3:369-77.

Rinaldi M, Vonella AV, 2006. The response of autumn and spring sown sugar beet (Beta vulgaris L.) to irrigation in Southern Italy: water and radiation use efficiency. Field Crops Res. 95:103-14.

Scopel E, Triomphe B, Affholder F, Da Silva FAM, Corbeels M, Xavier JHV, Lahmar R, Recous S, Bernoux M, Blanchart E, Mendes ID, De Tourdonnet $\mathrm{S}, 2013$. Conservation agriculture cropping systems in temperate and tropical conditions, performances and impacts. A review. Agr. Sustain. Develop. 33:113-30.

Sepaskhah AR, Kamgar-Haghighi AA, 1997. Water use and yields of sugarbeet grown under every-other furrow irrigation with different irrigation intervals. Agric. Water Manage. 34:71-9.

Soil Survey Staff, 2010. Keys to soil taxonomy, 11th ed. USDA-Natural Resources Conservation Service. Washington, DC, USA

UNESCO-FAO 1963. Bioclimatic maps of the Mediterranean zones. Mesnilsur l'Esrtrée, France.

Vamerali T, Ganis A, Bona S, Mosca G, 2003. Fibrous root turnover and growth in sugar beet (Beta vulgaris var. saccharifera) as affected by nitrogen shortage. Plant Soil. 255:169-77.

Venturi G, 1988. Colture alcoligene: aspetti agronomici. Accademia Nazionale di Agricoltura, Bologna, pp 61-100.

Venturi P, Venturi G, 2003. Analysis of energy comparison for crops in European agricultural systems. Biomass Bioenergy. 25:235-55.

Wight JP, Hons FM, Storlien J0, Provin TL, Shahandeh H, Wiedenfeld RP, 2012. Management effects on bioenergy sorghum growth, yield and nutrient uptake. Biomass Bioenergy. 46:593-604.

Wortmann CS, Liska A, Ferguson RB, Lyon DJ, Klein RN, Dweikat IM, 2010. Dryland performance of sweet sorghum and grain crops for biofuel in Nebraska. Agron. J. 2:319-26. 